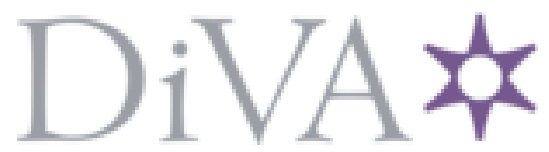

http://www.diva-portal.org

\title{
Postprint
}

This is the accepted version of a paper published in International Interactions. This paper has been peer-reviewed but does not include the final publisher proof-corrections or journal pagination.

Citation for the original published paper (version of record):

Bjarnegård, E., Melander, E. (2013)

Revisiting Representation: Communism, Women in Politics, and the Decline of Armed Conflict in East Asia.

International Interactions, 39(4): 558-574

http://dx.doi.org/10.1080/03050629.2013.805132

Access to the published version may require subscription.

N.B. When citing this work, cite the original published paper.

Permanent link to this version:

http://urn.kb.se/resolve?urn=urn:nbn:se:uu:diva-208114 
This is an Author's Accepted Manuscript of an article published in International Interactions 14 Aug 2014, available online: http://dx.doi.org/10.1080/03050629.2013.805132.

To cite this article use the following information: International Interactions, volume 39, issue 4, pages 558-574.

\section{Revisiting Representation:}

\section{Communism, Women in Politics, and the Decline of Armed Conflict in East Asia}

This research note evaluates one of the commonly used measurements for political gender equality: representation of women in parliament. It demonstrates that caution is called for when interpreting results where this variable is used, because parliamentary representation implies different things in different settings. Societies with more women in parliament tend to have fewer intrastate armed conflicts. We investigate this statistical association with a particular focus on the East Asia. This region has seen a shift from extremely intense warfare to low levels of battle deaths at roughly the same time as great strides have been made in the representation of women in parliaments. This research note shows, however, that this statistical association is driven by authoritarian communist regimes, promoting gender equality as a part of communist ideology, and whose representative chambers have little influence over politics. Using statistical tests and empirical illustrations from East Asia, the note concludes that the political representation of women is an invalid indicator of 
political gender equality in East Asia. There is thus a need to nuance the picture painted in earlier research. In addition, the suggestion that more women in parliament will lead to fewer armed conflicts runs the risk of being forwarded as an oversimplified solution to complex problem, and we briefly discuss the instrumentalization of gender equality in peace and security studies.

This research note takes a deeper look at the issue of parliamentary representation of women and what it means — or does not mean - for peace and security. Numerous statistical studies find a worldwide statistical association between peace, often measured as the absence of intrastate armed conflict, and gender equality, in several important studies measured as the percentage of women in parliament (for example, Caprioli 2000, 2005; Caprioli and Boyer 2001; Gleditsch, Wucherpfennig, Hug, and Reigstad 2011; Melander 2005a, 2005b). We argue that one should be very careful when interpreting results where the representation of women is used as an indicator of gender equality, because parliamentary representation implies very different things in different settings.

We show that parliamentary representation of women can be a poor indicator of genuine gender equality in certain contexts by using the example of East Asia. The East Asian setting is particularly well-suited for this type of investigation because several countries exhibit relatively high levels of female representation in parliament (for example, China, Laos, North Korea, and Vietnam). Nevertheless, these very countries are also examples of political settings where we have reason to question the validity of representation of women as a measurement of gender equality. These countries are all authoritarian communist regimes, promoting gender equality as a part of communist ideology, and whose representative chambers are not allowed much influence over politics. 
East Asia is also interesting as a case because the region has seen a remarkable shift from extremely intense warfare to very low levels of battle deaths (Tønnesson 2009) at roughly the same time as great strides have been made in the representation of women in parliaments. This is therefore one region where we would expect to find a strong correlation between the representation of women in parliament and the decline of armed conflict. It is, however, also a region in which we have ample reason to doubt that correlation implies causality. Theory suggests that one-party states also tend to avoid outbreaks of armed conflict partly because of harsh repression that quells any dissent before there is a possibility to organize for armed rebellion (Fjelde 2010). In this research note, we therefore explore the proposition that in East Asia communism is the driving factor behind both the high representation of women and behind the avoidance of armed conflict. We find that it is, indeed, difficult or even impossible to chisel out the effect of representation of women from the effect of communist regimes in East Asia.

Our finding is also reason to question some of the more simplistic assumptions about the role of women in peace-making, and it may thus contribute to a more nuanced scholarly debate. The fact that there are fewer armed conflicts in countries with more women in parliament easily lends itself to interpretations suggesting that women will make different decisions from those made by men, and that increasing the share of female decision makers hence should benefit peace directly. The use of parliamentary representation of women as a measurement of gender equality thus exacerbates an emerging discourse where the perceived difference of women is pragmatically used as an oversimplified solution to a very complex problem. Certainly, the concerns we raise do not imply that gender equality is unimportant in issues of war and peace. Rather, we make use of recent feminist critique of the instrumentalization of gender equality in general and UNSCR 1325 in particular to point to the idea that gender equality and the 
representation of women should be considered as issues of justice, in their own right, regardless of the consequences they bring about.

The research note will proceed as follows: We outline two distinct arguments for why it is unlikely that female parliamentarians will impact on nation-wide armed conflict patterns. We focus on communist countries for two reasons. Firstly, while communist countries tend to exhibit relatively high levels of women in parliament, their parliaments also tend to be weak political institutions. Secondly, literature also suggests that communist countries are particularly likely to be able to avoid open rebellion. In the empirical part of this research note, we therefore investigate whether the effect of parliamentary representation of women on intrastate armed conflict changes when communism is accounted for. We find that the communist regime type and higher levels of female representation in parliament in East Asia are so closely related to each other that it is difficult to statistically distinguish one effect from the other. We instead illustrate the hypothesis that this research note has generated with examples of the representation of women in East Asian communist countries. We end by spelling out the potential risks of instrumentalization of gender equality in the light of our findings and discuss their potential wider implications.

\section{Scrutinizing Representation}

The United Nations Security Council's Resolution on Women, Peace, and Security (UNSCR 1325) urges Member States "to ensure increased representation of women at all decisionmaking levels in national, regional and international institutions and mechanisms for the prevention, management, and resolution of conflict." Its language merely stresses that women should participate in the prevention and resolution of conflicts, as well as in peace-building. UNSCR 1325 has undoubtedly been an important tool for advocates of women's rights in 
conflicts. However, scholars and practitioners alike have pointed to the risk of UNSCR 1325 being used instrumentally in a broad "women, peace and security agenda." Implicit assumptions about the relationship between women and peace abound and affect the discourse that activists use (El Bushra 2007). UNSCR 1325 has been invoked to claim that the increased representation of women in different decision-making bodies is a necessity for sustainable peace (see, for example, Anderlini 2000). Such a use may reinforce, rather than eliminate, gendered stereotypes by essentializing women as mothers and nurturers, who are expected to have a pacifying effect on peace negotiations and decision making at large (Dornig and Goede 2010). Scholars from different fields see a more general trend that gender equality is increasingly being used as a tool, or an instrument, to meet other ends. When gender equality and women's rights are instrumentalized, they are no longer primarily valued as ends in themselves. Instead, they are used as means of efficiently implementing other policies and reaching other, more desirable, ends (cf. Bessis 2004; Cohn and Enloe 2003; Olivius 2011; Prügl 2011).

A rather large body of research has shown that, statistically, gender equality and peace are, indeed, connected. This relationship seems to be quite robust for different measures of gender equality (for example, women in parliament, fertility rates, education levels, duration of female suffrage, women in the labor force) (Caprioli 2000, 2005; Melander 2005a) and is sustained regardless of whether the focus is on international conflict (Caprioli 2000, 2003; Caprioli and Boyer 2001), intrastate conflict (Caprioli 2005; Gleditsch et al. 2011; Melander 2005a) or state human rights abuse (Melander 2005b). Our focus here is on evaluating one of the most commonly used measurements of gender equality - the parliamentary representation of women - and its impact on one of the most commonly used measurements of peace: intrastate armed conflict. 
Any statistical relationship needs a compelling causal story to underpin it. Burguieres (1990) staked out three principally different understandings of the relationship between women and peace. A first position views women as inherently pacific in contrast to bellicose men, and maternal thinking may, according to this perspective, be harnessed to advance peace. A second position rejects the stereotypical association of women with peace as disempowering and instead insists that women have a right to equal standing on issues of war and peace. The third position is based in the observation that "war is rooted in patriarchal, military structures which are supported by the behavior of both men and women" (1990:9), and entails that peace can benefit when both men and women change so that patriarchy and militarism are undermined.

Our first line of argument emanates from feminist literature and suggests that women cannot be treated as a unified category or be assumed to be peaceful by nature. We question the notion that increasing the representation of women in parliament should in itself lead to more peace, a notion which clearly pertains to the first position identified by Burguieres and which, in its most extreme form, suggests an essentialist view of women as naturally less violent than men (Fukuyama 1998; also Hunt 2007). It should be noted, however, that most feminist scholarship on issues of war and peace likewise rejects the essentialist view of women as inherently peaceful peacemakers, and instead adopts the second or the third position, or some combination of the two: women as a group have varied interests and priorities and women are not necessarily more peace-loving than men (see, for example, Gibson 1994; Gill 1997; Goldstein 2001; Hooper 2000; Tickner 1992, 2001, 2004). We thus share with many feminist scholars their skepticism against the stereotype of peaceful women as especially effective peacemakers.

The second argument is of a more empirical nature and points to evidence that women are often marginalized in the political process. Even if we were to assume that women are more peaceful and better peacemakers (regardless of whether we believe this is due to essential differences or 
to socialization and expectations), there are strong reasons to doubt that most female parliamentarians would have a discernible influence over the processes that determine whether a societal conflict escalates to warfare or can be managed peacefully. In other words, there is no convincing causal story that tells us how these women are able to implement country-wide policies leading to avoidance of conflict. This more pragmatic concern points to the need for a theoretical investigation of how and when women parliamentarians are, in practice, able to act autonomously and effectively to enact political change.

Female politicians often work in environments where is it very difficult for them to act efficiently for women, let alone bring about systemic changes. Early on, organizational studies suggested that it takes a rather large minority, somewhere around 30\%, in order for its members to be able to qualitatively affect a workplace environment (see, for example, Kanter 1977). The parliamentary minority that women constitute in most parliaments in the world is smaller than 30\%. Moreover, the growing field focusing on the substantive representation of women in politics is increasingly rejecting the idea of a "critical mass" (see, for example, Childs and Krook 2006). The proposition that it takes at least a $30 \%$ representation of women if women are to enact real policy change had, according to Dahlerup (2006), already been abandoned by political science research in the 1980s. Yet, outside the research community, the idea of a critical mass is "living a life of its own." The need for at least $30 \%$ women in parliament is very often used as an argument by practitioners and advocates for gender quotas (Dahlerup 2006). All these concerns notwithstanding, we will for completeness sake also test for a pacifying effect of a critical mass of women parliamentarians in the empirical analyses.

Instead, political science research has repeatedly pointed out that it is generally difficult for female politicians, regardless of the size of the minority they constitute, to enact change in a male-dominated environment. Much research emphasizes that institutions are embedded in 
masculine norms, and that women, especially if they do not conform to these norms, are marginalized (Carroll 2001; Childs and Krook 2006; Grey 2006). Women are required to follow the party line and are thus unable to depart from the norm and to enact change for women (Fiig 2009). We know that initiatives from women's organizations or from individual female politicians or peacemakers are often met with skepticism or they are marginalized and ignored (El Bushra 2007; Puechguirbal 2010; Väyrynen 2004; Valenius 2007). The causal story arguing that women politicians are able to bring about peace is therefore difficult to reconcile with conventional wisdom within the field of gender and politics.

Moreover, if the representation of women primarily increases in political bodies with little political influence, this increased presence of women is less likely to make a difference in politics. ${ }^{1}$ The parliamentary bodies in most communist countries play a ceremonial role, rubberstamping legislation initiated by the party-state leadership. Thus, parliamentarians in communist regimes in general do not have much real say on matters of national security, and it has been argued that this is particularly true for female politicians who are often there for show (Matland and Montgomery 2003; Waylen 2007). Importantly, however, because of socialist ideology, communist regimes often use quotas that lead to a relatively high formal representation of women.

Much of what we know about the influence of women parliamentarians in communist regimes, we have learnt from countries that have undergone transitions to democracy, Eastern Europe in particular. Being formally based on the works of Marx and Lenin, state socialist regimes have an almost inherent formal commitment to women's equality. All organization of women is, however, connected to the Communist Party. In most cases, efforts are made to ensure

\footnotetext{
${ }^{1}$ Melander $(2005 a ; 2005 b)$ notes this complication.
} 
representative political bodies containing a rather large number of women. These women are often put in place through "loose quotas" or guidelines on composition of the parliament. Women have thus reached considerable numerical representation in formal political bodies in most communist countries in the world. However, in Eastern Europe and the former Soviet Union, there have been very few women in the top party decision-making rank (Waylen 2007). Women have not reached leading or well-paid positions either in the labor force, or in politics, and they have been still burdened with the main responsibilities of household duties and child rearing (Matland and Montgomery 2003).

Eastern European countries have also seen a significant decrease in the representation of women since the fall of communism, indicating that the high representation levels were not indicative of the institutionalization of a genuinely gender equal society or of the political empowerment of women. Although the communist regimes contributed to an increase in women's participation in education, the labor force, and politics, women were not in a position to use these resources once a new polity emerged. It is thus to be expected that communist countries, also in East Asia, have a relatively high representation of women. From this, however, it does not necessarily follow that the women representatives assert actual influence over important policy decisions or peace negotiations. Although the problem of token representation of women in parliaments is a general one, we hold that female parliamentarians in communist states have particularly limited influence because of the authoritarian character of these regimes.

\section{Are Communist Countries Peaceful?}

Communist regimes tend to include many women in their rubber-stamp parliaments. In this section, we will also present the theoretical reasons for expecting communist regimes to also 
be particularly effective in avoiding open rebellion. Hence, the relationship between the representation of women in parliament and the avoidance of armed conflict could be spurious.

Fjelde (2010) points out that authoritarian one-party states, to which category communist regimes belong, are the least likely authoritarian regimes to be engaged in armed conflict. Regimes can deal with opponents in two principal ways: they can be repressed or they can be turned into supporters. There is reason to believe that authoritarian one-party regimes, such as communist regimes, should be particularly effective in coercion as well as in co-optation. The communist party in authoritarian one-party states is the "intrusive societal organization" that, according to Fjelde, is the most powerful instrument for identifying and repressing opponents. One-party communist states have often been very successful when it comes to subordinating the military to political control, and the political organization in itself also branches out into local areas. In addition, they often have efficient intelligence organizations. The party organizations also make one-party states better equipped to co-opt rebellion, by incorporating opponents into the party. There are also more possibilities for exceptional individuals, once they become supporters, to rise in rank and even to influence policy. Communist regimes can make use of a party organization that can contribute patronage and a long-term career. In socialist states, the large public employment sector is also only available through the government (Fjelde 2010).

Building on Fjelde, we thus argue that it is likely that there is a causal relationship between being a communist one-party regime and avoiding internal conflict. The fact that communist regimes avoid internal armed conflicts, however, should not be confused with the absence of repressive measures against citizens. In fact, Fjelde's argument rather points to the opposite: one party authoritarian states use coercion (as well as co-optation) efficiently-from the point 
of view of the regime - to quell any opposition that might otherwise spur internal uprisings and armed conflict. $^{2}$

\section{STATISTICAL ANALYSIS}

In the empirical part of this research note, we evaluate the effect of the parliamentary representation of women to see if its relationship to the onset of intrastate armed conflict disappears or is weakened when the confounding factor of communism is brought in. We use a standard cross-sectional time series country-year design, and include variables that are widely used, except for the new communist regime indicator that we have coded ourselves. We control for population size, economic development, a decay function of the number of years that a country has remained at peace, and regime characteristics other than the communist regime type (dummies representing the extent of institutional constraints on the decision-making powers of the chief executive, as well as institutional transition and collapse).

Although our focus in this research note is the role of representation of women in parliament, we also include an alternative measurement of gender equality to underline that there are other theoretical understandings of the role of gender for peace. Burguieres' (1990) third position pointed to patriarchal structures and values affecting both men and women. In our empirical tests, we therefore include the higher education attainment of women. When women are allowed to educate themselves and prepare for a career, it could be an indicator of women's views being more broadly valued and accepted. As women become more educated, the societal structures emphasizing militarized masculinity may be weakened.

\footnotetext{
${ }^{2}$ It is likely that most regimes - also democracies - use some degree of both co-optation and coercion, but for the reasons given above we believe that communist regimes will be particularly effective in this regard.
} 
We first analyze a global sample and then restrict the analysis to East Asia. Because of space restrictions, the design, variables, and sources of data are explained in more depth in the online appendix accompanying this research note.

In Table 1, we present six cross-sectional time series logistic regression models with the onset of intrastate armed conflict as the dependent variable. First, we replicate the gist of the research using the political representation of women as a key indicator of gender equality (for example, Melander 2005a). Model 1 uses all countries and years for which data are available.

\section{*** TABLE 1 ABOUT HERE ***}

In line with previous findings, women in parliament has a statistically significant peacepromoting effect. Model 1 also shows statistically significant effects of three potentially confounding variables: population size, economic development, and regime transition. Political institutions undergoing transition make a country more susceptible to armed conflict. Countries with larger populations are also more at risk, although the increase in risk diminishes with the absolute size of the population since the population measure takes the natural log of the population. Furthermore, economically more developed countries are less exposed to the onset of armed conflict. The indicator of national wealth, that is, gross domestic product per capita, is also log-transformed, meaning that the pacifying effect of further economic development diminishes in strength at higher levels of development. Model 2 adds the indicator of the communist regime type to the global sample used in Model 1. The effect of women in parliament is somewhat weakened, but both women in parliament and communist regime are statistically 
significant and have negative signs. The results for the control variables are very similar in Models 1 and 2. Importantly, both gender equality and communism are associated with peace within states also when the effects of regime transition, population, and economic development are accounted for. Note that peace years, regime collapse, and the dummies for the levels of executive constraints are not statistically significant. A large number of additional control variables were added one by one to Model 2 to further gauge the robustness of these effects, but none of the additional controls proved statistically significant (results on request).

Model 3 is a pruned, global model, using all country-years but keeping only the variables that were statistically significant in Model 2. The most notable difference between Models 3 and 2 is that the effect of communist regime is strengthened when the variables reflecting executive constraints are dropped. The result that communist regimes are less prone to intrastate armed conflicts is novel, but agrees with the gist of Fjelde's findings (2010).

Model 4 uses the alternative indicator for the political representation of women, namely critical mass (a dummy variable taking the value of 1 if women constitute at least $30 \%$ of parliamentarians). As expected, we find no support for the notion that a critical mass drives the relationship between political representation of women and peace. The effect of communist regime appears considerably stronger when this more coarse measure of gender equality is used.

Model 5 uses an entirely different indicator of gender equality, namely the female-to-male higher education attainment ratio (education ratio), and a global sample. Following Melander (2005a), we argue that this variable rather than the presence of women in political decisionmaking bodies reflects broad societal norms about the equal worth of women and men. Hence, Model 5 is less of a test of the notion that peaceful women bring about peace and more a test of an alternative argument suggesting that societies permeated with norms of equality are more 
peaceful. Thus, we confirm Melander's (2005a) finding that equality values are associated with peace, and we find that this association holds also when controlling for the communist regime type.

Model 6 examines the possibility that it is the set of seemingly stable communist regimes in East Asia that drives the results reported above. It uses only the observations from East Asia, and the same set of variables as in Model 3. The number of observations goes down drastically and, not surprisingly, the standard errors increase. The effects of regime transition and population are no longer pronounced enough to achieve statistical significance in the East Asian sample, and only the coefficient for the pacifying effect of economic development keeps the indication of statistical significance. Crucially, we can no longer discern any pacifying effect for female representation or the communist regime type.

The communist regime type and higher levels of female representation in parliament are closely related to each other in East Asia, just as we suspected they would be. Consequently, it is statistically difficult to detect any separate effects of these two variables with the amount of information at hand. The correlation between women in parliament and communist regime is 0.37 if using all country-years, and is 0.77 in East Asia. If either one of women in parliament or communist regime is dropped from Model 6, the other variable in the pair becomes significant. That is to say, also in the East Asian sub-sample, female parliamentary representation seemingly has a peace-promoting effect when the communist regime type is not accounted for, and likewise communist regimes seem more prone to peace also in the East Asian sub-sample provided that the potentially pacifying effect of female representation is ignored. 
We explicitly scrutinize the argument that women when placed in decision-making positions, by virtue of their difference from male politicians will contribute to a peaceful development by looking specifically at the role of communist regime types in East Asia. It is argued that communist regimes have been able to co-opt and coerce opponents, thus avoiding the outbreak of armed conflicts. Important for our evaluation of the validity of the variable representation of women as an indicator of the political influence of women is the fact that many communist regimes boast a relatively high level of women in their parliaments but that this probably has very little to do with their level of conflict. This is because women in communist parliaments face at least two problems, making them unlikely to enact real change: they are often a marginalized group working in a male-dominated environment, mainly for show; and parliaments in communist countries in general are powerless institutions. Next we briefly discuss examples of communist regimes in East Asia and the plausibility of a causal relationship between women in parliament and peace in the light of these examples.

\section{Communist Regimes in East Asia}

The communist regimes in East Asia have had comparatively high representation of women in their national assemblies. Most accounts, from most countries in the region, however, tell us that these national assemblies are not regarded as real power centers. Importantly, the real power centers do not have as high a representation of women.

North Korea is a case in point. This repressive government boasts a persistently high representation of women in its parliament, the Supreme People's Assembly. According to Shin (2001), however, women are not as well represented in the political bodies that hold some kind of real power. In 1990, for instance, there were 20 percent women in the Supreme People's 
Assembly. At the same time, there were only about 4 percent women in the more powerful North Korean Central Committee of the Workers' Party (Shin 2001).

A regime that we know more about is the People's Democratic Republic of China. As in most other communist cases, there were no outbreaks of intrastate armed conflict after the 1950s. In China, the measurement used for the commonly applied variable women in parliament reflects the percentage of women in the National People's Congress (NPC). The NPC has had a relatively high continuous representation of women. It is in many ways evident that this high representation of women is linked to communist ideology. For instance, there was a surge in the number of women parliamentarians around the time of the Cultural Revolution (approximately 1966-1976). Howell claims that "mass campaigns and feverish ideological struggle dragged women into the depths of politics" (Howell 2008:58) during this time. However, the NPC is much less powerful than the Central Committee of the Communist Party, which also generally has had a much lower representation of women. The Central Committee is elected by the NPC and appoints many of the most powerful positions in China, including the Politburo Standing Committee and the General Secretary of the Communist Party. For instance, the military arm of the People's Republic of China, the People's Liberation Army (PLA) is not subordinate to a state council, but to the Politburo Standing Committee. The Politburo Standing Committee thus passes down general guidance to the PLA through the Central Military Commission (Shambaugh 2002). Following the National Congress in 2012 the Politburo Standing Committee consists of seven male members. It has never had a female member (Park, 2012). The 25-member Politburo doubled its female representation in $2012-$ going from one to two women (Kang Lim and Martina, 2012). There has never been a female General Secretary of the Communist Party of China. Howell also argues that women at all levels of government tend to be assigned deputy positions as well as "softer" portfolios, suggesting 
they are not generally in a position to influence "hard" questions about war and peace (Howell 2008). Observers thus note that even if women are present in the NPC and in the All-China Women's Federation, they are, and have always been, absent from positions of real power in the party (Hunt 2007).

It is noteworthy that the two countries in the East Asian region that have abandoned communism, in parallel to the development in post-communist Europe, as a consequence have seen a sharp decrease of representation of women in parliament. In Cambodia, the representation of women increased drastically when the Communist Party of Kampuchea, better known as the Khmer Rouge, seized power. After the Paris Peace Agreement in 1991, more democratic elections were held and the representation of women decreased. ${ }^{3}$ Mongolia, a former Soviet satellite, followed the same pattern as Eastern Europe after the fall of communism. These two cases further illustrate the proposition that the representation of women is largely cosmetic in communist states. As soon as communism fell, so did the representation of women in both Asia and Eastern Europe.

\section{The Risks of Instrumentalizing Women and Peace}

The suggestion that representation of women will lead to less armed conflict is understandably compelling. It has been picked up by women's rights activists lobbying for the need to include a recommendation to increase the political participation of women in UNSCR 1325 - and who are now advocating for its implementation (El Bushra 2007). This suggestion presents itself as a "quick fix" to a complex problem. Rather than attempting to transform gender roles, it draws on already existing expectations and traditional understandings of male and female attributes

\footnotetext{
${ }^{3}$ Bjarnegård and Melander (2011) demonstrate that there is a general curvilinear relationship between the level of democracy and parliamentary representation of women in the shape of an inverted "U".
} 
and behaviors; however, it neglects the difficulty of women to reach substantive representation and "make a difference." This is the case in all political contexts but, as these cases illustrate, it is very evident in communist parliaments where the general weaknesses of national assemblies are combined with the constraints commonly put on female parliamentarians.

Importantly, if we accept the suggestion that women representatives will help us avoid violent conflict, there is a risk that the increased representation of women will lose value in itself. Being politically represented is no longer a matter of justice, but instead a means to an end. As Prügl notes:

Women's difference is no longer limited to their reproductive capacities and the productivity of their bodies, but is now recognized for its potential to deliver a range of ends, from profit and efficiency to growth and security. (Prügl 2011:79)

Bessis (2004) has identified a similar line of reasoning in the World Bank's thinking around economic development and gender equality. Women are no longer targeted because their economic rights are abused or because socioeconomic inequalities are gendered, but because they are increasingly seen as important economic actors and guarantors of social stability. By using these "new" economic actors in the right way, the World Bank can reach the paramount goal of economic development and poverty eradication.

In the longer-term perspective, however, instrumentalizing gender equality is risky. If gender equality does not have a value in itself, what will happen if other, seemingly more efficient tools are identified? Cohn has an answer to that:

When, on occasion, women's liberation is wielded instrumentally by any masculinized elite as a rationale-of-convenience for their actions, we should be 
on high alert; they'll put it back on the shelf just as soon as it no longer serves their longer range purpose. (Cohn and Enloe 2003:1203)

Instrumental arguments are often necessary and important in policy and advocacy and, as such, nothing that can or should be shunned. What should be avoided, however, is the spread of "gender myths and feminist fables" (Cornwall, Harrison, and Whitehead 2007) that essentialize women, effectively limiting their room for maneuver, and that may ultimately make matters worse for women if and when it is discovered that the reality is not that simple or straightforward. Important criticism has been directed more broadly toward the instrumentalization of gender equality in development (Cohn and Enloe 2003; Cornwall et al. 2007; Goetz 2007; Prügl 2011) as well as toward the suggestion that women are peacemakers more specifically (for example, El Bushra 2007). What we are particularly concerned about here is that the notion of statistical correlation between countries with more women parliamentarians and less armed conflict in those countries should remain unchallenged or be used as a baseline for further theorizing in that direction. While this criticism has been advanced before, we believe that the statistical analysis offered in this note is a unique contribution.

\section{CONCLUSIONS AND WAYS FORWARD}

This research note urges caution when using parliamentary representation of women as an indicator of political gender equality. We demonstrate that in East Asia, it is impossible to distinguish the effect that parliamentary representation of women has on armed conflict from the effect of a communist regime type. Communist regimes tend to have relatively high levels of women in parliament, but because parliaments in these countries have limited influence, it seems highly unlikely that individual women representatives would manage to affect security issues through parliament. Consequently, we suggest that the influence of peaceful female 
parliamentarians be dismissed as an explanation for the decreasing number of armed conflicts in East Asia.

The empirical analysis is here limited to an evaluation of representation of women as an indicator of female political influence in East Asia. Although not directly applicable to other regions, our findings suggest ways forward for evaluating the representation of women in other regional settings. For instance, international donor influence may have had an impact on the decreasing levels of violence as well as on the introduction of gender quotas in countries like Rwanda and Uganda. In an African post-conflict setting as well, we need to acknowledge that representatives operate within existing power structures, and that representation means different things in different polities. In this context, for instance, female parliamentarians are often placed in add-on seats, so called reserved seats, thus not being fully integrated in party affairs (Bjarnegård and Zetterberg 2011).

Our study of the East Asian region raises doubts about the validity of using the percentage women in parliament as an indicator of political gender equality when studying the determinants of war and peace. At least in East Asia, the association seems spurious and indicates the need for more research. Caution is advisable as far as this aspect of gender equality is concerned, both academically in drawing conclusions about causation, and policy-wise in advocating an increase in the number of female decision-makers as a direct way of promoting peace.

At the same time, we do not dismiss the emerging view that gender equality is causally related to peace. In our analyses, we also employ an alternative measure of gender equality (the ratio of female to male higher education attainment) and we demonstrate that this variable remains significantly related to peace on a global scale when controlling for communism. This measure 
instead points to a causal explanation emphasizing the importance of broad societal norm changes. In our view, the argument that value shifts in large segments of the male and female population lead to priority shifts and new views on the role of women and men as well as on conflict resolution in the public sphere is plausible and worth exploring. What we criticize is an essentialist picture of women as peacemakers in an otherwise unchanging society. Even if a couple of women were to be added to all peacekeeping forces, their influence would be limited if the masculine culture of these peacekeeping forces were to remain intact. We would even risk a backlash if women did not fulfill the high expectations that they are there to enact peace. Pointing to the need to focus on value changes and on altering the norms permeating masculine organizations such as parliaments and peacekeeping forces implies a much larger and slower process of change.

\section{REFERENCES}

Anderlini, Sanam Naraghi. (2000) Women at the Peace Table: Making a Difference. New York: United Nations Development Fund for Women (UNIFEM).

Bessis, Sophie. (2004) International Organizations and Gender: New Paradigms and Old Habits. Signs 29(2):633-647.

Bjarnegård, Elin, and Erik Melander. (2011) Disentangling Gender, Peace, and Democratization: The Negative Effects of Militarized Masculinity. Journal of Gender Studies 20(2):139-54.

Bjarnegård, Elin, and Pär Zetterberg. (2011) Removing Quotas, Maintaining Representation: Overcoming Gender Inequalities in Political Party Recruitment. Representation 47(2):187-99. 
Burguieres, Mary K. (1990) Feminist Approaches to Peace: Another Step for Peace Studies. Millennium: Journal of International Studies 19(1):1-18.

Caprioli, Mary. (2000) Gendered Conflict. Journal of Peace Research 37(1):51-68. . (2003) Gender Equality and State Agression: The Impact of Domestic Gender Equality on State First Use of Force. International Interactions 29(3):195-214.

—. (2005) Primed for Violence: The Role of Gender Inequality in Predicting Internal Conflict. International Studies Quarterly 49(2):161-78.

Caprioli, Mary, and Mark A. Boyer. (2001) Gender, Violence, and International Crisis. Journal of Conflict Resolution 45(4):503-18.

Carroll, Susan J. (2001) The Impact of Women in Public Office. Bloomington: Indiana University Press.

Childs, Sarah, and Mona Lena Krook. (2006) Should Feminists Give up on Critical Mass? A Contingent Yes. Politics \& Gender 2:491-530.

Cohn, Carol, and Cynthia Enloe. (2003) A Conversation with Cynthia Enloe: Feminists Look at Masculinity and the Men Who Wage War. Signs: Journal of Women in Culture and Society 28(4):1187-1207.

Cornwall, Andrea, Elizabeth Harrison, and Ann Whitehead. (2007) Gender Myths and Feminist Fables: The Struggle for Interpretive Power in Gender and Development. Development and Change 38(1):1-20.

Dahlerup, Drude. (2006) The Story of the Theory of Critical Mass. Politics \& Gender 2(4):491530.

Dornig, Sven, and Nils Goede. (2010) Ten Years of Women, Peace and Security. In INEF Policy Brief: Universität Duisburg Essen. 
El Bushra, Judy. (2007) Feminism, Gender, and Women's Peace Activism. Development and Change 38(1):131-147.

Fiig, Christina. (2009) Women in Danish Politics: Challenges to the Notion of Gender Equality. In Women and Politics around the World: A Comparative History and Survey. Vol 2., edited by Joyce Gelb and Marian Lief Palley. Santa Barbara, CA: ABC CLIO.

Fjelde, Hanne. (2010) Generals, Dictators, and Kings: Authoritarian Regimes and Civil Conflict, 1973-2004. Conflict Management and Peace Science 27:195-218.

Fukuyama, Francis. (1998) Women and the Evolution of World Politics. Foreign Affairs $77(5): 24-40$.

Gibson, James William. (1994) Warrior Dreams: Paramilitary Culture in Post-Vietnam America. New York: Hill and Wang.

Gill, Lesley. (1997) Creating Citizens, Making Men: The Military and Masculinity in Bolivia. Cultural Anthropology 12(4)(:527-50.

Gleditsch, Kristian Skrede, Julian Wucherpfennig, Simon Hug, and Karina Garnes Reigstad. (2011) Polygyny or Misogyny? Reexamining the "First Law of Intergroup Conflict." The Journal of Politics 73(1):265-70.

Goetz, Anna Marie. (2007) Political Cleaners: Women as the New Anti-Corruption Force? Development and Change 38(1):87-105.

Goldstein, Joshua S. (2001) War and Gender: How Gender Shapes the War System and Vice Versa. Cambridge: Cambridge University Press.

Grey, Sandra. (2006) Numbers and Beyond: The Relevance of Critical Mass in Gender Resarch. Politics \& Gender 2(4):491-530.

Hooper, Charlotte. (2000) Manly States: Masculinities, International Relations, and Gender Politics. New York: Columbia University Press. 
Howell, Jude. (2008) Gender and Rural Governance in China. In Women's Political Participation and Representation in Asia, edited by Kazuki Iwanaga. Copenhagen: NIAS Press.

Hunt, Swanee. (2007) Let Women Rule. Foreign Affairs 86(3):109-20.

Kang Lim \& Michael Martina. (2012) “China's Politburo has more women, is younger - but barely." $\quad$ Reuters. $\quad$ November 2012. http://www.reuters.com/article/2012/11/15/china-congress-politburoidUSL3E8MF1VR20121115

Kanter, Rosabeth Moss. (1977) Men and Women of the Corporation. New York: Basic Books.

Matland, Richard E., and Kathleen A. Montgomery. (2003) Women's Access to Political Power in Post-Communist Europe. Oxford: Oxford University Press.

Melander, Erik. (2005a) Gender Equality and Intrastate Armed Conflict. International Studies Quarterly 49(4):695-714.

_. (2005b) Political Gender Equality and State Human Rights Abuse. Journal of Peace Research 42(2):149-66.

Olivius, Elisabeth. (2011) Humanitarian Assistance and the Politics of Gender Equality: A Study of Refugee Camps on the Thai-Burma Border. In Building Peace, Creating Conflict? Conflictual Dimensions of Local and International Peacebuilding, edited by Hanne Fjelde and Kristine Höglund. Lund, Sweden: Nordic Academic Press.

Park, Madison. (2012) "Woman could break the political glass ceiling." CNN. November 12, 2012. http://edition.cnn.com/2012/11/08/world/asia/china-women-politics

Prügl, Elisabeth. (2011) Diversity Management and Gender Mainstreaming as Technologies of Government. Politics \& Gender 7(1):71-89.

Puechguirbal, Nadine. (2010) Discourses on Gender, Patriarchy and Resolution 1325: A Textual Analysis of UN Documents. International Peacekeeping 17(2):172-87. 
Shambaugh, David. (2002) Civil-Military Relations in China: Party-Army or National Military? Copenhagen Journal of Asian Studies 16:10-29.

Shin, Eun-young. (2001) Ideology and Gender Equality: Women's Policies of North Korea and China. East Asian Review 13(3):81-104.

Tickner, J. Ann. (1992) Gender in International Relations. New York: Columbia University Press.

—. (2001) Gendering World Politics. New York: Columbia University Press.

—. (2004) Feminist Responses to International Security Studies. Peace Review 16(1):4348.

Tønnesson, Stein. (2009) What Is It That Best Explains the East Asian Peace since 1979? A Call for a Research Agenda. Asian Perspective 33(1):111-36.

Valenius, Johanna. (2007) A Few Kind Women: Gender Essentialism and Nordic Peacekeeping Operations. International Peacekeeping 14(4):510-23.

Väyrynen, Tanja. (2004) Gender and UN Peace Operations: The Confines of Modernity. International Peacekeeping 11(1):125-42.

Waylen, Georgina. (2007) Engendering Transitions: Women's Mobilization, Institutions, and Gender Outcomes. Oxford and New York: Oxford University Press. 
Table 1. Women in Parliament, Communism and Onset of Intrastate Armed Conflict

\begin{tabular}{|c|c|c|c|c|c|c|}
\hline & Model 1 & Model 2 & Model 3 & Model 4 & Model 5 & Model 6 \\
\hline \multirow{2}{*}{$\begin{array}{l}\text { Women in } \\
\text { Parliament }\end{array}$} & -0.046 & -0.037 & -0.036 & & & -0.050 \\
\hline & $(0.015)^{* * *}$ & $(0.015)^{* *}$ & $(0.015)^{* *}$ & & & $(0.045)$ \\
\hline \multirow[t]{2}{*}{ Population Size } & 0.097 & 0.098 & 0.099 & 0.086 & 0.081 & 0.112 \\
\hline & $(0.035)^{* * *}$ & $(0.035)^{* * *}$ & $(0.034)^{* * *}$ & $(0.036)^{* *}$ & $(0.045)^{*}$ & $(0.102)$ \\
\hline \multirow{2}{*}{$\begin{array}{l}\text { Economic } \\
\text { Development }\end{array}$} & -0.466 & -0.483 & -0.490 & -0.492 & -0.473 & -1.016 \\
\hline & $(0.143)^{* * *}$ & $(0.144)^{* * *}$ & $(0.096)^{* * *}$ & $(0.152)^{* * *}$ & $(0.163)^{* * *}$ & $(0.406)^{* *}$ \\
\hline \multirow{2}{*}{ Peace Years } & -0.007 & -0.019 & & 0.035 & -0.410 & \\
\hline & $(0.311)$ & $(0.307)$ & & $(0.308)$ & $(0.352)$ & \\
\hline \multirow[t]{2}{*}{ Constraints 1} & 0.246 & 0.268 & & 0.242 & 0.673 & \\
\hline & $(0.366)$ & $(0.367)$ & & $(0.363)$ & $(0.426)$ & \\
\hline \multirow[t]{2}{*}{ Slight Constraints } & 0.090 & 0.132 & & 0.113 & 0.428 & \\
\hline & $(0.313)$ & $(0.320)$ & & $(0.324)$ & $(0.348)$ & \\
\hline \multirow[t]{2}{*}{ Constraints 3} & 0.509 & 0.456 & & 0.376 & 0.502 & \\
\hline & $(0.551)$ & $(0.556)$ & & $(0.550)$ & $(0.755)$ & \\
\hline \multirow{2}{*}{$\begin{array}{l}\text { Substantial } \\
\text { Constraints }\end{array}$} & 0.517 & 0.474 & & 0.449 & 0.894 & \\
\hline & $(0.286)^{*}$ & $(0.289)$ & & $(0.293)$ & $(0.383)^{* *}$ & \\
\hline \multirow[t]{2}{*}{ Constraints 5} & 0.078 & 0.034 & & -0.008 & 0.351 & \\
\hline & $(0.417)$ & $(0.423)$ & & $(0.430)$ & $(0.522)$ & \\
\hline \multirow[t]{2}{*}{ Executive Parity } & 0.217 & 0.179 & & 0.125 & 0.877 & \\
\hline & $(0.475)$ & $(0.474)$ & & $(0.493)$ & $(0.595)$ & \\
\hline \multirow[t]{2}{*}{ Regime Transition } & 1.113 & 1.091 & 0.897 & 1.040 & 1.519 & 0.611 \\
\hline & $(0.495)^{* *}$ & $(0.501)^{* *}$ & $(0.435)^{* *}$ & $(0.511)^{* *}$ & $(0.554)^{* * *}$ & $(1.015)$ \\
\hline \multirow[t]{2}{*}{ Regime Collapse } & 0.273 & 0.234 & & 0.241 & 0.383 & \\
\hline & $(0.602)$ & $(0.617)$ & & $(0.646)$ & $(0.754)$ & \\
\hline \multirow[t]{2}{*}{$\begin{array}{l}\text { Communist } \\
\text { Regime }\end{array}$} & & -0.806 & -0.871 & -1.136 & -1.710 & -1.504 \\
\hline & & $(0.400)^{* *}$ & $(0.391)^{* *}$ & $(0.385)^{* * *}$ & $(0.979)^{*}$ & $(1.014)$ \\
\hline \multirow[t]{2}{*}{ Critical Mass } & & & & -0.659 & & \\
\hline & & & & $(1.006)$ & & \\
\hline \multirow[t]{2}{*}{ Education Ratio } & & & & & -0.594 & \\
\hline & & & & & $(0.237)^{* *}$ & \\
\hline \multirow[t]{2}{*}{ Constant } & -1.219 & -1.097 & -0.888 & -1.072 & -1.729 & 3.483 \\
\hline & $(1.066)$ & (1.068) & $(0.756)$ & $(1.095)$ & $(1.300)$ & $(2.344)$ \\
\hline $\mathrm{N}$ & 5,664 & 5,664 & 5,664 & 5,664 & 3,966 & 525 \\
\hline
\end{tabular}

